petition for no-tuition admissions. Students who are not being sponsored by a company often find themselves unable to continue their studies beyond the first year-due to lack of funds.

Many domestic experts on higher education rank tuition fees, complemented by means-tested financial aid and student loans, among the most effective ways to stabilize and expand higher education in Russia. Yet in a context of state austerity, compounded by strenuous economic challenges, such a solution can only be a long-term proposition.

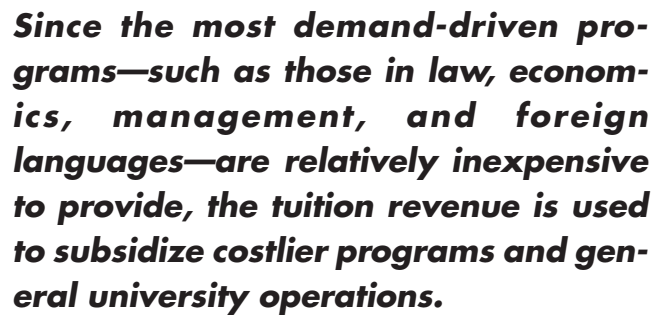

A proposal for introducing means-tested financial assistance came at the end of 1997 when the overall education reforms were being contemplated. However, the important issue of mechanisms for means-testing was not discussed. In any event, the proposal got stalled as being too radical to accept in its major components. In the short run, the major thrust of the reforms was to use available resources more effectively and to stimulate investments in education. The proposals recommended tax deductions on investments in higher education for both enterprises and individuals, needs-based student financial aid to target poor and out-of-town students-the amount of financial aid to be at least at the minimal subsistence level-and a for-fee expansion of auxiliary campus services with assistance for needy students.

These measures were aimed at stimulating resource flows to higher education from nonstate sources- that is, from businesses and individuals. The goal was to redirect resources from the "shadow" sector into a legal sector of education, to mitigate the growing inequality in access to higher education, and to decrease undifferentiated state subsidies for auxiliary campus services. There were counterarguments to these recommendations, and in early 1998 the proposed reform plan was not supported by Parliament. However, responding to the continuing pressure of state financial cuts, policymakers offered to lift the cap on tuition-based enrollments in public institutions, decrease the student-faculty ratio, redirect state financial aid solely to the needy, and reduce state-supported admissions. The last proposal triggered a number of student protests against the privatization of higher education. According to a student survey in the Urals, almost two-thirds of respondents expressed concern about their inability to complete their studies on a fee-paying basis, and only one-quarter indicated that they would be able to carry the full costs of higher education.

A rise in the number of state-supported admissions to public higher education has been reported as of fall 1999 . Yet the problems have continued to mount in higher education since the August 1998 financial setback. Recently, national policymakers have called on university leaders and other professionals to make a concerted brainstorming effort to come up with possible solutions. With the parties admitting the need for change, the effort is expected to reinvigorate higher education.

\title{
The University of Malta's Student Stipend System
}

\section{Ronald G. Sultana}

Ronald G. Sultana directs the Comparative Education Program in EuroMediterranean Studies, and is the head of the Department of Foundations in Education at the University of Malta. He was dean of the Faculty of Education (1997-1999) and is the founding editor of the Mediterranean Journal of Educational Studies. Address: Faculty of Education, University of Malta, Msida MSD 06, Malta. E-mail: <rsul1@educ.um.edu.mt>; web page: <http://www.educ.um.edu.mt/mep/mep.htm>.

t a time when the major trend in universities internaAtionally is for students to share at least some of the costs of their higher education, Malta remains what may well be a unique case: the government provides not only free instruc-

tion but also a stipend to all undergraduates. The stipend system originated in a series of reforms at the University of Malta ushered in by a Labour government in the 1970s. The reforms included, among other things, the introduction of a "student-worker scheme," whereby all students were obliged to find an employer-sponsor before being allowed access to a university degree program. Students were required to spend five months studying and five months working. In this way, the then government hoped to attract students from different socioeconomic backgrounds into postcompulsory education, ensure that graduates found employment, and encourage a shift away from the university's traditional focus on the old professions into new, more vocationally relevant areas. Students received a wage-pegged in the first year of sponsorship to half the salary of a clerk in the civil service, in the second year to that of an administrative assistant, and in 
the third year to that of an administrative officer. In return, students were contractually bound to work for their sponsor for a certain number of years.

\section{The stipend system originated in a series of reforms at the University of Malta ush- ered in by a Labour government in the 1970 s.}

During the course of its 25 years in existence, the student-worker scheme encountered severe criticism because it introduced a numerus clausus, with entry being regulated by the condition of sponsorship; because it was based on a model of graduate manpower planning that was unresponsive to changes in the country's small, open economy; and because it brought about a major shift in Malta's traditional university culture, hitherto conservatively liberal in orientation. ${ }^{1}$ Despite such criticisms, however, subsequent governments of different ideological orientations found it impossible to dismantle a system that had provided financial independence to students. As a result, with the "refoundation" of the University of Malta in 1987 after the election of the center-right Nationalist Party, the student-worker sponsorship system was dropped and a stipend introduced for all students. Students were no longer required to find employer-sponsors, or to work-the argument being that studying itself was work. Constantly drawing on comparisons between high rates of university attendance in Europe and relatively low ones in Malta, the government justified the new stipend system in terms of its potential to attract young people to postsecondary studies.

The stipend system has gone through various changes. In particular, the system was challenged on the grounds that the state can no longer afford to be so generous to students who are, in the main, already financially comfortable - coming as they tend to do from the middle- and upper-middleclass backgrounds. In addition, government promotion of higher enrollment levels has helped to send student numbers shooting up from just under 1,500 in 1987, to 7,500 10 years later, with dramatic financial consequences for state coffers already hard-pressed by an escalating structured deficit. The siphoning off of scarce public funds for higher education has had another consequence- that of starving the compulsory school sector from much-needed investment. As a result, the university has seen its budget increase exponentially but to the detriment of basic education-with illiteracy rates among school-age children remaining as high as 12 percent. This state of affairs does not make economic sense: it has led to an oversupply of both overqualified and underqualified person- nel and a staff vacuum at middle-management, supervisory, and technical levels.

Despite these and other criticisms, and given the delicate balance of both political and class power on the island, no government has quite dared to tamper with the stipend system in any radical manner. At best, new conditions have been placed to regulate access to the stipend: between 1995 and 1997, for instance, a series of legal notices prohibited the grant of stipends to repeaters, to students over 30 years of age, and to most graduate students. An attempt to transform part of the stipend from a check handout to a book voucher was met by protests on the part of the student body. A Labour government argued that it was immoral to subsidize university studies to such a degree when other sectors of the education system were starved for funds. Worse still, there was evidence that the stipend was contributing to the consumeroriented lifestyles of the middle classes, given that Maltese youth tend to live with their parents until they get married. In the 1997 budget provisions, the Labour government therefore reduced the stipend to a flat monthly rate of $\operatorname{Lm} 50$ monthly (U.S.\$125) and a further Lm50 monthly on a loan basis. In 1998, a board was also set up to consider the needs of students from financially deprived backgrounds, who could qualify for an extra Lm50 monthly.

\section{Subsequent governments of different ideological orientations found it impos- sible to dismantle a system that had pro- vided financial independence to students.}

In the most recent development in the saga, the Nationalist Government-which had made an campaign promise to reform the stipend system in favor of university studentshas just announced a new scheme. Students will now get a lump sum of Lm400 (U.S.\$1,000) to buy equipment such as computers, and another one-time sum of Lm200 (U.S.\$500) to buy books. They will then get Lm60 (U.S.\$150) monthly for the duration of their studies.

It has been observed that the middle classes have a way of mobilizing themselves to benefit from free services offered by the state, rerouting in their direction money from the public coffers-even when it is meant to promote equity. Malta's university student stipend system is a perfect illustration of how such a strategy can be exploited.

\section{Note}

1. R. G. Sultana, "Problems in Equalizing Access to Higher Education: Policy Lessons from Malta," Higher Education Policy 8, no. 3 (1995). 